\title{
Religious War: Al-Qaradawi During the Wars in Gaza
}

\author{
Shaul Bartal \\ Bar Ilan University, Ramat Gan, Israel
}

\begin{abstract}
Since Israel's withdrawal from the Gaza Strip in August 2005, it has already conducted over three wars and a few other operations against Hamas. The last Gaza War lasted 50 days (July 7-August 26, 2014). This article shows how this conflict is in actuality a war between Islamic nationalism (represented by Hamas) and Jewish nationalism (represented by Israel). In this constant state of conflict, Hamas is supported by the famous Sheikh Yusuf al-Qaradawi, a Muslim Brotherhood scholar and the head of the International Union of Muslim Scholars and other well-known Islamic institutions. An analysis of Qaradawi's views on the wars in Gaza explains why jihad in Palestine will continue and why there is no possible compromise solution. According to Qaradawi, the war against Israel is the most important type of jihad in the Arab world today (and not in Syria and Iraq). This is the first and foremost of all Muslim problems and must be supported by all Muslims. The Gaza Strip is only one battlefield in this war.
\end{abstract}

Keywords: Gaza War, Hamas, Israel, Qaradawi, Palestine, Egypt, Izz ad-Din al-Qassam Brigades

\section{Religious War: Al-Qaradawi During the Wars in Gaza}

In June 2006, the Israel Defense Force (IDF) began military operations with the purpose of harming Hamas in the Gaza Strip. The first Gaza Strip operation began as a response to the kidnapping of Gilad Shalit on 25 June 2006 and was called "Summer Rain". It was discontinued due to the break out of the second Lebanese War one week later. On 31 October 2006, operation “Autumn Clouds" began. In this operation, the IDF entered the Gaza Strip in the area of Beit Hanoun and Beit Lahia which are located in the northern end of Strip. On 26 November 2006, after the deaths of over 400 Palestinians in the Gaza Strip, the operation drew to a close (Ali, 2009, pp. 85-89). These two military actions took place at a time when the Fatah organization, under the leadership of Muhammad Dahlan, was still the ruling factor in the Gaza Strip under the Palestinian Authority. At this time, Dahlan was still fighting his opposition and dealing with rising criticism by the Hamas organization on his performance. The June 2007 takeover of the Gaza Strip by Hamas and the establishment of Hamas control over the Strip by the removal of all Fatah operatives, led to a period of repeated rounds of war between Israel and the Hamas organization and its supporters in the Strip, a policy which has been described as "lawn mowing" (Inbar, September 1, 2014).

In the period of time since the Hamas revolution in June 2007 until today, there have been four Israeli military operations aimed at weakening the Hamas regime and reducing the amount of rockets launched at Israel from the Gaza Strip as much as possible. Although operations "Warm Winter" (27 Feb. 2008-4 Mar. 2008) and "Cast Lead" (27 Dec. 2008-1 Jan. 2009), cost over 1,600 deaths, it led only to a relative period of 
quiet. Israel's success in these operations was limited (Ali, 2009, pp. 87-95). Hamas was able to rehabilitate itself, renew its rocket strength and even successfully increase the firing range of the air strikes on Israeli targets. A large part of the Hamas organization's success in retaining its abilities stems from the financial and military aid that it received from Qatar. This financial aid enabled Hamas to not only rehabilitate the Strip physically but to purchase weapons as well. The financial, political and public support given to Hamas from around the world also included monies from the charity committees. Sheikh Yusuf al-Qaradawi's support which stemmed from his position as the Director of the International Union of Muslim Scholars (IUMS) and head of the trustees of the International Jerusalem Institute insured that a major part of the monies collected as part of tithing in the Islamic law (zakat) went to the Hamas organization (The General National Security Service, Shabak, September 2009; Drori, 2014, pp. 3-4).

After the "Cast Lead" operation in 2009, Sheikh Yusuf al-Qaradawi actively raised significant funds for the rehabilitation of the Gaza Strip after the Israeli attacks. He did this in the framework of his position as the Director of IUMS by diverting donations from the international charity organizations that he had established, E'itilaf Al-Khair (The Charity Coalition), to Hamas. In addition, Qaradawi, operating from Qatar (his place of residence), convinced the local ruler (Hamad bin Khalifa Al Thani) to support the Hamas organization economically and politically (Izz ad-Din al-Qassam Brigades, January 29, 2009). This article will survey Qaradawi's contributions to Hamas during the last two Israeli operations.

\section{Qaradawi's Support for Hamas During “Operation Pillar of Defense"}

On 14 November 2012, the IDF began Operation "Pillar of Defense". The operation's purpose was to limit the amount of rockets fired into Israel from the Gaza Strip. This operation began with the assassination of Ahmed al-Jabari, the Deputy Commander of the Izz ad-Din al-Qassam Brigades (the military arm of Hamas), who was the actual commander in the field. Under Hamas rule, over 169 Gaza residents died and over 800 were injured during the operation. In addition, there was mass destruction of foundations and public buildings. The operation led not only to an Israeli military achievement but to a Hamas political achievement as well (Bartal, November 18, 2012). This operation took place during the period of the blossoming of the Arab spring where the Islamic parties won elections in Tunis, Morocco, Egypt and Yemen. It appeared as if the Muslim Brotherhood would, in another minute, win control over the whole Arab world thereby making it possible for their vision of an Islamic Empire to become a reality. For the first time, Hamas was granted political recognition for the legitimacy of its rule from the states of the Arab League. Ismail Haniyeh, the prime minister of the Hamas government, began to receive Arab foreign ministers and the heads of the Arab governments who expressed support and unequivocal recognition for Hamas in Gaza to the dissatisfaction of the President of the Palestinian Authority (PA), Mahmoud Abbas (Abu 'Amer, January 2013, pp. 32-33). Credit for these achievements should also be given to Sheikh Yusuf al-Qaradawi who, already on the second day of Operation Pillar of Defense, came to the aid of the Hamas organization. In his visit to Egypt he was able to find fertile ground for stirring up anti-Israel feelings in the state where the president, Mohamed Mursi, was a member of the Muslim Brotherhood.

Sheikh al-Qaradaw also serves as a member of the al-Azhar Committee of Muslim scholars, the most influential law institution in the Islamic world. Qaradawi's words from within the al-Azhar organization were 
widely broadcast throughout the Arab states. Qaradawi called for Islamic Arab unity against the mutual enemy of the Islamic nation and the strengthening of the spirit of the children of Palestine in Gaza. Qaradawi's words were broadcast on Friday, 16 November 2012, on the same historic day that the Egyptian Prime Minister Hesham Mohamed Qandil visited the Gaza Strip. Qaradawi said: “They [the Muslim States] have to prove to the whole world that they are one [Islamic] nation which can clash with all of the [aggression] of a nation from among its people [like in Palestine]" (Maktab al-Filastini lil-l'alam, November 16, 2012). Qaradawi also added a condemnation of "those same religious leaders of the Islamic nation who do not arise against Israel and its evil, boastful deeds" (Maktab al-Filastini lil-l'alam, November 16, 2012).

The revolutions in the Arab world, where the Islamic movements connected to the Muslim Brotherhood, came into power in Egypt, Tunisia, Morocco and Yemen. This led to an Islamic Arab world much more willing to aid the Palestinians in their struggle. In his sermon, which was broadcast throughout the Arab world from al-Azhar, Qaradawi called for a joint mass march of all Arabs for the freedom of Gaza and for aid to the children of Palestine. In his call to the Arab states and especially to the rule of the Brotherhood in Egypt, Qaradawi demanded the cancellation of the peace agreement, the breaking off of relations with Tel Aviv and the return of the Arab ambassadors to their own countries. Qaradawi's call did not fall on empty ears. A number of Arab states expressed support for the Hamas government and this included a procession of Arab foreign ministers to Gaza. Thus, Hamas' political gain became an actual one-de facto recognition for its government (Bartal, November 18, 2012). For example, Egypt recalled its ambassador from Israel as a result of the Israeli operation, but it did not cut off its diplomatic relations with Israel and even took a significant role in stopping the fighting between the two sides. This shows that despite the evident influence of Qaradawi on the supporters of the Moslem Brotherhood throughout the world with an emphasis on Egypt, his political influence on the regime was limited. In the meantime, the regime of the Muslim Brotherhood prefers its political interests over its political recommendations. Likewise, despite widespread support, as much as it was, not a single Arab state went out of its way to help Hamas in its war against Israel. Hamas senior personnel expressed their disappointment with the reactions of the Arab world which were not effective enough in putting enough pressure on Israel as had been expected (Kam, 2012, pp. 22-23).

What is Qaradawi's contribution to Hamas' political achievements for that same period? The contribution is enormous. He aided in the realization of the first visit to the Gaza Strip by an Arab leader since the Hamas Revolution in June 2007-the visit of the Emir of Qatar Hamad bin Khalifa Al Thani on 23 October 2012. During this visit, the Emir of Qatar purposely skipped over a similar visit to the Palestinian Authority in Ramallah thereby, through his actions and his monetary support, showing his belief in the legitimacy of the regime and in the Hamas ideology. His shunning of the Palestinian Authority led to criticism by the government of Salam Fayad and the president of the Palestinian Authority Mahmoud Abbas. Heniyah also announced the establishment of a new city near Khan Yunis which would carry the name Hamad in honor of the historic visit which symbolized an historical turnabout in the diplomatic recognition of the Hamas regime. Nothing was left for Mahmoud Abbas other than to express his objections to the visit and to hope that it would not affect the efforts which in the end succeeded - the signing of an appeasement agreement between the two movements (Issacharoff, October 24, 2012; Haaretz, October 23, 2012).

In an article published on the Izz ad-Din al-Qassam Brigades' site, Qaradawi is quoted as saying that it 
was his influence on Emir Hamad bin Khalifa Al Thani which was responsible for the historical visit of the Emir of Qatar to the Gaza Strip during Operation Protective Edge and for the actions of the rest of the governmental factors in Duha where he has lived since the 1960s (Izz ad-Din al-Qassam Brigades, January 23, 2013). Qaradawi explains that his close ties with the president of Qatar began right after the Gaza War which resulted in the deaths of 1,415 martyrs and left 5,450 people injured. As head of a delegation of religious sages, Qaradawi met with the Emir of Qatar and asked him to intercede on the behalf of the Hamas government in Gaza to help fight the Israeli aggression. According to al-Qaradawi, it was him who succeeded in awakening the enthusiasm of the Emir of Qatar to the distress of Gaza and to the Palestinian matter and that the Emir committed himself in front of him to do as much as he could in regard to the Gaza problem (Izz ad-Din al-Qassam Brigades, January 29, 2009). In the beginning, the Emir of Qatar did, in fact, try to aid in the realization of an internal appeasement with the sponsoring of the Duha Agreement between the two sides_Fatah and Hamas, signed in Qatar on 6 Feb. 2012 (Issacharoff \& Khuri, February 6, 2012). But, when this agreement failed to lead to the awaited for appeasement, the Emir took independent political action which was in opposition to the stand of the Palestinian Authority and the official stand of the Arab League at that time. The Emir came to the Gaza Strip on an official state visit - the first time of an Arab leader to the Strip since the Hamas gained control in 2007.

\section{Operation Protective Edge}

On July 8, the "Operation Protective Edge" broke out in the Gaza Strip. This operation was carried out in a number of stages that included air strikes, limited ground entry and the assassination of the leaders of the Izz al-Din al-Qassam Brigades. The most high profile assassinations were against the leaders and founders of the Izz ad-Din al-Qassam Brigades: Muhammad Ibrahim Salah Abu Shamala (Abu Khalil), a member of the upper military council, Raed Subhi Ahmad al-Attar (Abu Eyman), the commander of the Rafah district, the "mastermind behind the abduction of Israeli soldier Gilad Shalit" (Albany Tribune News, March 14, 2014) and a member of the upper military council and Mohammed Hamdan Barhoum, (Abu Osama) (Izz ad-Din al-Qassam Brigades, August 21, 2014). Also included the attempted assassination of Muhammad Deif (chief commander of the Izz ad-Din al-Qassam Brigades). During the assassination attempt the following were killed: Deif's wife, Widad, his son, Ali, and his daughter Sara were killed (Levi, Kais, \& Somfalvi, 2014).

From the first day of the operation, Qaradawi supported Hamas and encouraged it and the rest of the Palestinian factions to continue with their opposition and their jihad against Israel. IUMS, in an opinion written by Qaradawi which was already published on the second day of the war, on July 9th, called on all the governments and the Islamic and the Human Rights organizations to stop the Zionistic violence. At the same time, Qaradawi called for the "Palestinian nation to continue in its struggle through a third intifada" and for the "Palestinian nation to continue to steadfastly hold on to the land of Palestine against the exploiting Zionist occupier" (Qaradawi, July 9, 2014a).

Qaradawi's messages, as expressed in the last Gaza war, are a continuation of the consistent content in his speeches and sermons in regard to the duty of jihad in Palestine. A number of these messages were repeated in different contexts even during the Cast Lead Operation (27 December 27 2008-18 January 2009) and the Pillar of Defense Operation (14-21 November 2012). The fifty-day battle in this round of fighting enabled Qaradawi 
to decisively express his views supporting Hamas and to emphasize many other additional motifs.

\section{The Most Important Jihad is in Gaza}

For those fighting on the land of al-sham [a nickname for the land of Greater Syria which includes Jordan, Lebanon and Israel] and to all those who turn to Gaza [and who carry out] the jihad in Gaza, this is the most important jihad on the land of al-sham. This is my ruling for this hour, everything that is related to [the struggle] on the land of Gaza. Gaza is calling you!! Where are the jihad fighters and the free men? Hey, the children of Umar-al-Faruq [a nickname for Amar Ibn al-Khatib, the second Caliph during whose reign Jerusalem and the land of Israel were captured]! (Qaradawi, July 23, 2014).

The struggle in the Gaza Strip is part of the ongoing struggle between the Zionistic Jews and the Islamic nation. This crucial struggle demands to be resolved in a way which is in favor of the children of the nation who are protecting themselves from an anti-Muslim attacking force which the Egyptian regime of Abdel Fattah Saeed Hussein Khalil el-Sisi put together. In light of this, the drafting of every son of the nation is the requirement of the hour. In a declaration made by at the beginning of the fighting, Qaradawi warned of fabricated religious rulings and emphasized that his religious stand is constant and is expressed in his books, his writings and his sermons which deal with the issue of Palestine and which require fighting in Palestine - against people and property (Qaradawi, August 9, 2014).

From among his books, Qaradawi indicates three significant ones which emphasize his ideas on the importance of jihad in Palestine. He believes that jihad is a defensive jihad and therefore it is within the realm of personal responsibility (fard al-'ayn). These are: (1) A lesson in the second nakbeh [1967]—Why we were defeated and how we can win). This book was published immediately after the Six-Day War (Qaradawi, 1993); (2) Jerusalem, the problem of every Muslim (Qaradawi, 2001a); (3) The encyclopedia of the laws of jihad (Qaradawi, 2009).

Fighting for jihad in Gaza takes religious precedence over fighting for jihad in other sectors where there is a struggle between Muslim and Muslim such as in Syria and Iraq. Fighting in Gaza against the Jews proceeds any fighting against Christian infidels such as the United States fighting in Afghanistan. Jihad is graded according to the level of the importance of the area to Islam. This ideology also stems from Qaradawi's anti-Semitic approach which describes the struggle against the Jews as a cosmic struggle between good and evil that began at the dawn of Islam (Qaradawi, 2001b, pp. 61-69).

The understanding that jihad is on a graded scale with jihad in Palestine at the top of the list of priorities is expressed by the words of the members of the Islamic movement in Israel such as Sheikh Ra'ed Salah Mahagana and Sheikh Kamal Khatib. The Islamic Movement in the Northern sector is headed by Raed Salah and is part of the Muslim Brotherhood movement and is a sister organization to Hamas in Palestine (Bartal, 2012, pp. 84-95). But, keep in mind that these Islamic leaders, like their counterpart Hamas activist Dr. Ismail Heniyah, are members of the IUMS headed by al-Qaradawi.

Palestine, according to Sheikh Kamal Khatib, is a central problem of the nation and will stay like that. The crisis in Iraq in which the Islamic State of al-Iraq and al-Sham (ISIS) organization is involved, and the crisis in Syria, Lebanon and Egypt are not the central problems of the Islamic nation. The importance of jihad in Palestine stems from the position of Jerusalem and al-Aqsa in Islam. Khatib emphasized that the qibla (the 
direction of the Islamic prayer) towards al-Aqsa is the Muslims' important qibla. It was the first qibla in Islam and it will return to that status. It is the role of the religious sages to support the Palestinian struggle which will indicate the renewed importance of Jerusalem in Islam (Qaradawi, August 21, 2014).

The reason for Khatib's strong stand as he expressed it at the General Assembly of the IUMS which took place in Istanbul is:

Due to the religious ruling of the Jewish sages who permit the settlers to break into the al-Aqsa mosque and to plan its destruction while rebuilding the fake Holy Temple (al-Hikal al-Mazoum). How can it be that the Jews would make such a religious ruling and the Islamic sages will be quiet? (Qaradawi, August 21, 2014)

This stand by Khatib is not new and represents the ideas of Hamas and the Muslim Brotherhood. In a proclamation published by the Harakat al Kifah al Islami [Islamic Struggle Movement] before the first intifada in July 1983, which was, already, at that time, identified with the Muslim Brotherhood, it said:

Hey, masses of the Muslim nation, what are the Jews, the descendants of the apes and pigs, doing to us?... What is this pure blood of our sons that flows every day between us without being avenged?... What is this violence that is being carried out against us by our armed enemies which satisfies its lust for blood?... The Jews' program is one since they came to your Holy Land, settlement, harassment, acts of slaughter, wholesale migration, the hostile hearts spit from their hatred to Islam and as a preparation for their decisive attacks on our holy places in order to erase the al-Aqsa Mosque and rebuild their false Holy Temple... There is nothing before us except to rise up and there is nothing in front of us except for jihad, there is nothing before us except for war against the enemies of Allah. We must fight them with every possible means and all of the places, without pity. (Shabi \& Shaked, 1994, pp. 62-63)

The content of this proclamation is repeated time and time again, up until today, by the people of Hamas and the Islamic Jihad and you can find these expressions in Qaradawi's works as well.

On 10 July 2014, during Ramadan, after Muhammed Abu Khdeir was murdered and his murderers revealed, and after Operation Protective Edge and after the first reports and sights of the destruction in Gaza, Qaradawi publicized his call to come and protect Jerusalem, "Palestine and Jerusalem are the \#1 Islamic problems in importance" (Qaradawi, July 10, 2014). The struggle in Jerusalem today is an additional struggle,

The division [of the Temple Mount] and the expulsion, oppression and Judaization of the city in order to turn it into a Jewish capital. This is while destroying the Arab and Islamic character and the expulsion of its Jerusalemite residents. The [Zionist] occupation is in a race against time and therefore it is trying to set facts on the ground. (Qaradawi, July 10, 2014)

According to Qaradawi, Israel is using the internal instability in many areas of the Muslim nation in order to carry out the dangerous plan. The dangerous plan referred to by Qaradawi is the destruction of the al-Aqsa Mosque and the building of a temple on its ruins.

The enemies' [the Jews'] plans, which are using the events in Syria and Egypt, are gradually advancing... They are building beneath al-Aqsa and they are creating a blockade on top of al Aqsa. Thus, they are preventing the entry of Muslim worshippers. The threat against al-Aqsa is one that has been going on a long time and is permanent. That is why I am declaring that the problem of Palestine and the problem of Jerusalem and al-Aqsa is a Muslim problem of the first degree. (Qaradawi, July 10, 2014)

It is not just the problem of the Palestinians alone but of all the Muslims. Thus, despite the fact that Muslims in Egypt, Syria, Lebanon and Iraq also face internal difficulties, the most important place for jihad is still in Palestine due to the holiness of Jerusalem and the constant threat on it by the Jews. Qaradawi, as head of 
the trustees of Muasasat al-Quds al-Dawliya (International Jerusalem Institution) calls for the religious leaders to be aware of their job and their responsibility to support the struggle over Jerusalem and to endow Islamic awareness on the city. In addition, Qaradawi called out to all Muslims, wherever they are, to support Jerusalem and the struggle of the sons of Palestine for it. The struggle of Hamas in Gaza is a part of the religious struggle between the Muslim believing community and the infidel community (Qaradawi, July 10, 2014).

In light of this, it is not surprising that at the conference of the IUMS, which took place in August 2014 immediately after the Gaza Operation, Salah Aruri raised his voice. Aruri is a member of Hamas' political bureau and a founder of the Hamas' military arm in the West Bank. Aruri, originally from the village of Arura near Ramallah) today lives in Turkey and is the man who approved the action of the kidnapping of the three boys. This kidnapping led to the war in Gaza. At the general conference he made no mention of the kidnapping at all. It was reported that Aruri:

Updated those present on what was generally happening in Palestine and what was specifically happening in Gaza. He detailed what happened during the racist and barbaric [Zionist] wars, the strangling blockade [on Gaza]. He described the exploiting settlements and the Judaization of the respected Jerusalem - a Judaization which is expressed by a change in the building and the division of al-Aqsa according to the timetable [a time for Jews and a time for Muslims] and also in the division of the al-Aqsa plaza between the sides [Jewish space and Islamic space. (Qaradawi, August 24, 2014)

The Forth IUMS Conference was organized in Istanbul, the capital of Turkey between 20-22 Aug 2014. Those attending the conference included Rashid al-Ghannushi, the leader of the Islamic party, Al-Nahda (Rebirth) which won the elections in his country. The combination of Kamal Khatib, Salah Aruri and Qaradawi once again shows the ties among the Islamic movement in Israel, Hamas and Sheikh al-Qaradawi.

In addition to the holiness of Jerusalem and al-Aqsa in Islamic tradition which justifies the fact that jihad in Palestine is the most important today, al-Qaradawi argues that the war in Gaza, is, in practical terms, a war of existence, a war without a choice:

Israel is the one that started the war in Gaza which the opposition will of course use and will behave heroically... for the Palestinians] the war is a matter of existence... the opposition is linked and God will enable it to win. (Qaradawi, July $21,2014)$

The way to Jerusalem passes through the victory of the opposition in Gaza as expressed by the Hamas leaders after the Protective Edge operation was concluded (Madina al-Quds, September 5, 2014a; Madina al-Quds, September 5, 2014b).

\section{Jihad in Palestine is a Religious Obligation That Falls on Every Muslim}

The kidnapping of the three Israeli boys and Israel's military operations against the Hamas in the month of June led to the opening of another round of Palestinian-Israeli blood-letting. These events led to a barrage of rockets toward Israel from the Hamas side. As a result of this, Operation Protective Edge broke out. Mass demonstrations by Palestinians took place in Hebron area, Qalandiya, Nablus, Jerusalem and in the refugee camps while searches took place for the three young men. It made a deep impression on Qaradawi that they were called a third intifada. Already in the first days of the military operation against Hamas in Gaza, the IUMS publically called out to all of the Islamic and Arabic countries and to all of the nation's children to break out and support the struggle of the Palestinian nation (Qaradawi, July 9, 2014a). In another public declaration, 
Sheikh Ali Al-Qaradaghi, Qaradawi's deputy, called for an Islamic and Arabic intifada for Palestine and Jerusalem (Qaradawi, July 7, 2014a; Qaradawi, July 9, 2014a).

On 2 July 2014, the shocking murder of Muhammed Abu Khdeir of the Shu'afat neighborhood in Jerusalem took place. An energetic police investigation resulted in the arrest of a number of Jewish suspects for the deed. According to the confessions of the suspects, the murder was carried out as revenge for the three boys, Ayal Yifrach, Gilad Shaar and Naftali Frenkel who had been killed earlier by Hamas members. The media exposure of the murderers and their motives, on July 6th, led to an IUMS public declaration which called for violent opposition to the Zionists and Israel. The fatwa (religion order) of Qaradawi was publicized on 7 July 2014, the day that the war broke out according to the Hamas organization. ${ }^{1}$ In this fatwa, al-Qaradawi criticized the inappropriate silence of the Arab and Islamic world and all of the rest of the nations of the world and the international community:

Jewish extremist criminals murdered a Palestinian boy and burned him in occupied Palestine... In light of this the Palestinian nation has the full right to protect its occupied land in any way possible without any limitations of any kind... (Qaradawi, July 7, 2014a)

That is how a single event, condemned by all Israeli government factors, was turned into a justification for Hamas' terrorist activities and the IUMS position. As a result of the exposure of Muhammed Abu Khdeir's murderers on the first day of the new Gaza War a detailed clear call was issued:

We, IUMS call on the Islamic and Arabic nations, their people and governments to wake up and support the Palestinian nation. One needs to solve the Palestinian problem and strengthen the Palestinian nation which is fighting for its just rights and for the protection of its holy places which have fallen prey to a wicked conqueror. They must carry the responsibility as God, may He be praised commanded: "O you who have believed, if you support Allah, He will support you and plant firmly your feet”. (Surat Muhammad (47), v. 7)

In a different interview which was publicized after the war, on September 2nd, Sheikh al-Qaradawi indicated that, "Islamic law demands that we as Muslims together protect Gaza" (As-Sharq channel, September 2, 2014).

In a fatwa publicized by the IUMS on July 27th, Sheikh al-Qaradawi, the head of the organization, together with Sheikh Ali Al-Qaradaghi, the general secretary of the organization, announced that: The support for Gaza is a religious requirement (wajeb shar'ai) on all Muslims. Muslims must take all steps that they have at hand in order to remove the aggression from the people of Gaza (Qaradawi, July 7, 2014b).

This is the most significant steadfast position and the Muslims are required to support it. How will this support be expressed? In a public declaration, Qaradawi detailed all of the steps that need to be taken by the Muslims worldwide. Qaradawi is aware of the general character of the campaign and that jihad is not only in the soul but also with money, in the pen, in demonstrations and awareness.

(1) Inside of Palestine: It is up to the Palestinians in the West Bank and Jerusalem to demonstrate and protest against the Israeli activities in Gaza. They must make the Palestinian cities burn until the world intifada will awaken - especially the intifada in the Arab countries, in other words, a continuation of the revolutions against the Arab leaders.

(2) To reveal unity of the entire public by standing steadfast alongside the people of Gaza.

\footnotetext{
1 According to Israel, the first day of the war was July 8, 2014.
} 
(3) A call to all of the free nations of the world to act for the true and just rights of the Palestinian nation in Gaza which includes the removal of the blockade, the opening of the crossing points, the enabling of every son of Palestine to pray at the al-Aqsa Mosque, the return of the sons of Palestine to their land and an end to the Zionist occupation.

(4) A demand to the whole Arab and Islamic nation to support the struggle of the people of Gaza and to act inside of their countries and inside of the international community in order to put pressure on the occupation to stop the aggression in Gaza.

This public declaration concludes with the verse: "And Allah is not unaware of what you do" (al-Baqarah (2), v. 74). The explicit call by Qaradawi and the IUMS, whose home base is in Europe, to Muslims to take all steps including encouraging "spontaneous" demonstrations against the aggression in Gaza, led to dozens of stormy mass demonstrations around Europe - in Berlin, Paris, London, Belgium with most of them made up of Muslims living in Europe. These demonstrations were aimed against the Israeli fighting in Gaza. "Israel is a Terrorist State" cried the masses. In addition, they also called for the boycotting of Israeli products since economic support for Israel is also support for the Israeli War Machine.

\section{Hamas is not a Terrorist Organization}

One of the songs heard over and over again on the al-Aqsa Radio and Radio al-Quds which are identified with the Hamas organization and which are active in the Gaza Strip, was a song that dealt with jihad and its significance. The chorus of the song emphasized that jihad is not terror. Due to the Egyptian definition of the Islamic Brotherhood as a terror organization, Qaradawi comes out strongly against the description of Hamas as a terrorist organization, especially by the Egyptian regime. Hamas is an organization that protects the Palestinian people and represents the Islamic nation. The political approach of the Egyptians, Israel, the European states and the United States which present Hamas as a terrorist organization causes a disaster and disrupts the attempt of awareness of the Islamic opposition. "Muslims have a right to continue with their opposition until the freedom of their land" (Qaradawi, July 21, 2014). The argument that Hamas is a terrorist organization is in the realm of "continuous brainwashing but the opposition will continue to stand steadfast and Allah will grant it victory” (Qaradawi, July 21, 2014). In his book, Fiqh al-Jihad, Qaradawi described Israel as the real terrorist state (Qaradawi, 2009, pp. 1078-1080). Hamas irhab (terror) is legitimate according the Sari'a. Israel counterterrorism acts are not legitimate (Qaradawi, 2009, pp. 1082-1085).

This is also the reason that the spokespersons for Hamas over the years explain time after time that the activity of the kidnapping soldiers or settlers is not terror, Thus, for example, Ibd al-Aziz Rantisi, the head of Hamas from Gaza who was assassinated in April 2004 about a month after Sheikh Ahmad Yassin was assassinated in similar circumstances, explained after the first abduction of policeman senior sergeant, Nissim Toledano in December 1992:

This activity is not a terrorist activity. The Hamas movement is characterized by activities against Israeli soldiers. If there is something that can be called terror it is the actions of the armed Israeli army against our nation's unprotected citizens... activities against soldiers is not terrorism in any sense of the word. (Shabi \& Shaked, 1994, p. 17)

In a spine-tingling manner, similar words were said by Khaled Mash'al, chief of Hamas Political Bureau, when he referred to the responsibility of his organization in the abduction of the three boys, who were 
kidnapped at the Gush Etzion junction by a Hamas cell from Hebron under the command of Hossam Qawasmeh. Qawasmeh received the money for this action from the Hamas government in Gaza (Lake, August 5, 2014). On the Shubaka Palestine Ll-Hawar site, which is identified with Hamas, and on additional sites, it is emphasized (according to Mash'al) that:

The soldiers and the settlers in the West Bank are aggressors who are living in a way that is against [international] law on stolen land. Therefore, the Palestinian nation has the right to resist [which includes hurting them]...Netanyahu's comparison of the Hamas [organization] to "extremist groups" [like ISIS] is a lie and is aimed at influencing the general opinion of the community. We are an independence movement and not a violent organization. (Ynet, August 23, 2014; Shubaka Filastin lil-hawar, August 23, 2014)

In an interview on al-Jazeerea on July 15th, al-Qaradawi explained that the reason for the rejection of the Egyptian initiative by the Hamas organization stems from the fact that the Egyptians defined the Hamas and the Muslim Brotherhood as terrorist organizations. How can Egypt define the Muslim Brotherhood as a terrorist organization, remove a president elected in democratic elections, Muhmmad Mursi, arrest over 40,000 Muslim Brotherhood activists and torture them? Egypt cooperates with Israel on the blockade on Gaza and then presents itself as a mediator. Al-Qaradawi asks: "How can one have faith in the regime of [Abdel Fattah] al-Sisi?" (Al-Jazeera, July 21, 2014).

\section{Islamic Solidarity}

That is the motif that is repeated in all of Qaradawi's declarations and in all of his campaigns against Israel. Qaradawi used his stand as the head of the IUMS and ruled that it is necessary to support the people in Gaza. The behavior of the Arab nations was described by him as "a scandalous embarrassment" (Qaradawi, July 21, 2014). It is "up to the Muslims to extricate themselves in order to support the men of Gaza in any way that they can, in spirit, with money and in prayer" (Qaradawi, August 9, 2014).

Haram [It is a sin] to the Muslim nations which sit [all over the world] in the East and the West. They are watching Gaza which is under attack by [Israel] Land Sea and Air Force and they will abandon her to her fate [without help]. (Qaradawi August 9, 2014)

Every Muslim must aid as much as he can, even adding an additional plea for the people of Gaza is acceptable. During the Ramadan holiday and after ten days of war, al-Qaradawi indicated that:

At the beginning of the tenth night [of the war] we turned to God, the believers, that he would grant victory to our brothers in Gaza and that he would destroy their enemies and ours and the extorting Jew. (Qaradawi, July 19, 2014)

The struggle by the men of Gaza influences the respect of the entire Islamic nation. From this it follows that the success of the opposition in Gaza positively influences the members of the entire Islamic nation and not just the men of Gaza.

The courageous steadfastness of the members of the Gaza family raised up the heads of the [Islamic] nation. They are fighting with great strength against the Zionists and others. I am with them and strengthen the hands of the children of Gaza and the [West] Bank!!! (Qaradawi, July 26, 2014)

The fighting force against the children of Palestine is made up not only of Zionists but also of those who support Zionists. Qaradawi does not describe who the others are, but all those who support Israel from among the Christian nations are immediately turned into the enemies of Islam and everything that stems from 
that.

Because of this, it is clear that one cannot abandon the children of the Palestinian nation to their fate.

Islam imposes an obligation on the Arab and Islamic states to support the opposition in Gaza with food, medicine and arms. Islam requires the unity of the nation in all of the many countries of the Islamic Motherland, despite the distances between them. It is not possible that we will abandon the opposition alone [in the campaign]. (Qaradawi, July 22, 2014)

According to al-Qarawadi, the idea of an Islamic nation is not an amorphous concept lacking meaning. When part of the nation is hurt, it is the responsibility of the other part of the nation to protect it. The battle for Palestine, the struggle between Israel and Hamas, is seen as a cosmic struggle, one between the Jewish-Zionist nation which is supported by those who oppose Islam and the Muslim world. The battle has no borders because in the end we are talking about a struggle of life and death between Judaism and Islam. Thus, Qaradawi adopts Sayyid Qutb's view of the world as it was described in his book, Our war against the Jews (Qutb, 1993, pp. 20-38). ${ }^{2}$

From a practical point of view, Qaradawi presents fundamental criticism against the Arab nations which, in his opinion did not do enough in order to support the opposition and abandoned it in its struggle against Israel. According to him, it is the duty of the Arab and Muslim states to support the opposition just as the Jews support the State of Israel (Qaradawi, July 21, 2014).

Qaradawi's deputy, the general secretary of IUMS, Sheikh Ali Al-Qaradaghi, was more blunt. On July 20th, after what was called the "Shuja'iyya slaughter", the Sheikh criticized the:

Arab and Islamic silence on these acts of slaughter which hurt the rights of our Palestinian brothers in Gaza...the denouncement of their happiness at the misfortune of the Palestinians and the continuation of their coordination with Israel to the detriment of the Palestinians. (Qaradawi, July 20, 2014)

He asked: What type of Islamic unity is this? Who is supposed to lead the Islamic nation in its continuing struggle against the forces opposing Islam?

According to al-Qaradawi, he would like this to be Egypt but, to his sorrow, at this time there is an evil regime which he believes will quickly disappear (Qaradawi, July 22, 2014). In light of this, Qatar and Turkey are the leading countries in the Muslim world today. The harsh criticism by Qaradawi about Egypt under the leadership of Abdel Fattah al-Sisi touches many parameters of Egypt's conduct. Thus, for example, consider his attitude toward the Rafah crossing as an Egyptian-Arab-Islamic crossing. Qaradawi asks:

By what right does Abdel Fattah al-Sisi allow himself to take away the natural rights of all of the rest of the members of the united Islamic nation to pass through this crossing. "Are we not one nation and one Islamic entity"? (Al-Jazeera, July 21, 2014)

The Islamic nation is 1.7 billion Muslims. There is not one country or any Muslim who lives alone. It cannot be that Muslims will be killed at the same time that other Muslims are saying we are alone; we are not connected to them. Egypt is not alone, neither is Tunisia, etc. (Al-Jazeera, July 21, 2014).

While it is true that Egypt does indeed receives a lot of fundamental criticism for standing on the sidelines and cooperating with Israel, the rest of the Arab states are not absolved from criticism either. This criticism is expressed in the caricatures and the many articles on the various Hamas sites.

\footnotetext{
${ }^{2}$ Sayyid Qutb (died 1966) was one of the leading philosophers of the Muslim Brotherhood who is originally from Egypt.
} 


\section{Personal Example}

In light of all this, al-Qaradawi tries to serve as a personal example in his honest attempt to solve the Palestinian problem:

All my life I am proclaiming the obligation of jihad in Palestine against Israel the occupier and extortioner. From the year 1948 until today, I have not stopped doing this and if at this time I was able, I would hurry to Palestine to fight. I have called and I have not stopped shouting out for jihad in Palestine. The problem of Palestine is first and foremost our problem and it will not be forgotten [by us]. (Qaradawi, August 9, 2014)

According to Qaradawi, the last war in Gaza in the summer of 2014 is not a specific war that was aimed at protecting the people of Gaza from the cruel Israeli attacks. We are not talking about a war between an Islamic organization and a sovereign nation that is fighting against the attacks upon its citizens. We are talking about a crucial battle, a stage in the war for the freeing of Palestine, a war that began from the moment that the State of Israel was created in the year 1948 and which has continued until today. It is a war that will only end when the jihad organizations succeed in destroying the Israeli army and freeing Palestine. Qaradawi remembers with yearning the year 1948, when the military companies of the Muslim Brotherhood participated in the fighting in the land of Israel (Khaled as-Sa'ad, 2003, p. 180). Qaradawi himself was of course one of those youngsters who practiced for the war in Palestine, but, due to his bad luck, he did not fight in Palestine (Qaradawi, 2002, p. 264).

What is the purpose of the 'ulamā (religious sages) in the present round of the Jewish-Islamic struggle in Gaza? According to Qaradawi, the job of the religious sage is an active one of leading the nation. This view brings al-Qaradawi very close to the world outlook of Ruhollah Khomeini which is based on the religious principles of the religious sages who are leading the nation on a straight path (Khomeini, 1969). The job of the men of the cloth is not only to explain the Qu'ran and the Hadith but it is "their responsibility to rise up and stand alongside the Palestinian Opposition" to aid in the resistance, to lead the masses and to aid all of the believers in every part of the Islamic Motherland (Qaradawi, July 22, 2014; Qaradawi, July 26, 2014).

Qaradawi and the rest of the religious sages who were members with him in IUMS attacked the religious leaders who opposed them. This applies to the religious sages who came out against the Hamas organization because it rejected the Egyptian initiative which was announced by General Abdel Fattah al-Sisi after only one week of war on July 15th. As a result of this, Qaradawi related with disdain toward the 'ulama who criticized the Hamas organization:

Those from among the 'ulamā of Egypt who attack Gaza, the majority of whom are from among the supporters of Husni Mubarak and the rest of the corrupt organizations. (Qaradawi, July 21, 2014)

The Islamic religion, according to Qaradawi's view of the world, requires a united stand among all of the 'ulamā for their support of the people of Gaza. The 'ulamā who dare to express a different view are condemned for their views. According to Dr. Ahmad al-Risuni, the religious sages who support the steps that Egypt has taken are demonstrating their corruption (Qaradawi, July 9, 2014a). Sheikh Ali Al-Qaradaghi came out with a moving call to the Muslim governments to support Hamas and he warned the religious sages and the rulers that "God will punish those who engage in treason and will give him what he deserves" (Qaradawi, July 20, 2014) Any criticism of the Muslim Brotherhood or of the Hamas organization is seen as treason against the Islamic nation and as a type of heresy in the eyes of Qaradawi and the rest of the 'ulamā in IUMS. 
Qaradawi emphasizes that he has nothing against the Egyptian people and that his criticism of Egypt is one that stems from his role as a religious leader. He is a part of IUMS which has many members from among the 'ulama of Egypt. It is his responsibility to criticize the Egyptian regime. "I am a part of the nation... fellah [peasant] Ibn Fellah and the whole Egyptian nation love me..." (Al-Jazeera, July 21, 2014). According to Qaradawi, a religious leader, especially one in our time, bears a responsibility. A religious leader needs to say his words without fear according to the shriy'a.

In a conference which took place after the conclusion of the Protective Edge operation, a whole session was held dedicated to the role of the religious Muslim sages and their responsibility in the present time. Seven sessions were dedicated to the role of the religious sages. Thus, for example, the first session dealt with the role of the religious leaders in building a base on the way of wasatiyyah (the Islamic middle path about which al-Qaradawi preached) and its renewal. The seventh session dealt with the role of the religious sages in the problems of the nation in light of international law. In addition, there was a special session dedicated to Palestine and Jerusalem. The purpose of the religious sages is not just to guide the believers in the matters of the shriy'a but also to lead, support and aid them in problem solving, especially in regard to the most difficult and complicated problem of them all — the problem of Palestine (Qaradawi, August 24, 2014).

In light of this, it is not surprising that in the summation meeting of the conference the conclusions of IUMS in regard to the problems of Palestine were in the spirit of Hamas and included a call to aid the Palestinian nation as much as possible.

What took place in Gaza throughout the month of Ramadan and in these days was the crude aggression of the enemy Zionist occupier, an enemy which undertook deeds of a massacre and war crimes against innocent citizens by destroying their homes, refugee shelters, government buildings, educational institutions, mosques and others. (Qaradawi, August 24, 2014)

The bodies of the United Nation and the Security Council did nothing to aid the refugees and even supported the occupier.

In light of this, IUMS made five practical decisions:

(1) Jerusalem retains its respected religious and historical place. It is the center of the Islamic nation and represents its pride. All of the plans to Judaize the occupation will not change in light of this truth;

(2) There is no replacement for the role of Jerusalem in the Islamic nation and therefore we cannot allow any concessions on it - not even on a little finger of the holy city;

(3) IUMS announces its loyalty to and responsibility for the protection of the nations' holy places. The Palestinian nation takes part in the burden willingly, without being coerced. One cannot grant a present to whoever does not work to achieve this;

(4) The union announces its opinion to all parts of the nation headed by the religious sages who stand at the head of the nation and who will act to prevent the occupation and the division of the al-Aqsa Mosque or control of it. Likewise, they will act to stop the series of daily attacks and outbreaks against al-Aqsa;

(5) Opposition to the occupation is a legal right that has been bought as part of God's plan and international charters. That is why the union announces that one should keep the ammunition of the opposition in all of Palestine and especially in Gaza. The union also announces and calls with all of its might that it is strictly prohibited to leave the ammunition of opposition which is one of the items that believers are commanded to do. 


\footnotetext{
And prepare against them whatever you are able of power and of steeds of war by which you may terrify the enemy of Allah and your enemy and others besides them whom you do not know [but] whom Allah knows (Surat al-'Anfāl (8), v. 60).
}

These are the proclamations of the IUMS organization on the issue of Palestine. In a public statement summary, hope is expressed that the freeing of al-Aqsa is coming close and the day will come when the children of Palestine will come to pray in the blessed mosque when they are "free and winners". They bring the full support of the participating negotiating delegations on the part of the Palestinians and represent the unity of the Palestinian nation against the occupier and wish them success in achieving the victory (Qaradawi, August 24, 2014).

\section{Conclusions}

In the Arab/Muslim world, there are no other problems that have received so much attention in books and articles as the Palestinian problem has - not the Syrian regime which is slaughtering its own people, not ISIS which is a threat to the Shiites in Iraq, nor Lebanon which represents the world outlook of the Muslim Sunni-Salafi radicals. If there is one thing that can unite the entire Islamic world, radicals and moderates, it is against a common hated enemy-Israel and the Jewish people. According to the speeches of Sheik Yussuf al-Qaradawi who is seen as a central Islamic philosopher with relatively moderate views when it comes to the many Islamic issues, his views in regard to Israel are seen as very similar to those of the other Islamic Jihad organizations.

Qaradawi's outlook is consistent and loyal to his words which were already publicized in his books in 1968 as a reaction to the Arab defeat in the Six Day War (Qaradawi, 1993, pp. 41-42). The war against the Zionist Jews is a religious war. It is a war between a mighty Islamic nation which has over 1.7 billion and the Jewish nation which has about 14 million Jews. There are no separate Arab nationalities. There is just one nation - the Islamic nation. In the Pillar of Defense Operation in 2012, this Arab Islamic unity was expressed through visible political expression conducted by the victory of Muhmmad Mursi. In contrast, in the Protective Edge Operation, under the leadership of Abdel Fattah al-Sisi, the songs changed. During the 50 days of Operation Protective Edge, the Arab League did not meet even once to discuss the problem of Palestine. The feeling among Hamas was that unlike the political blossoming that took place in 2012, in 2014 they were alone. This feeling was also expressed in al-Qaradawi's speeches.

Egypt received special criticism from Qaradawi. To his consternation, the Egypt of Salāh ad-Dīn al-Ayubi (who died 1193) remained uninvolved and on the sidelines during this war. They instituted closures of the Rafah crossing and they arrested over 40,000 Muslim Brotherhood activists. Instead of leading the nation and providing aid and support to Hamas and the Palestinians, it did just the opposite, it pressured the opposition and helped the Israeli occupation. According to Qaradawi, there is no Egyptian nationalism; there is only Islamic nationalism (al-Jazeera, July 21, 2014). The Egyptian behavior is especially grating when compared with the conduct of Muhmmad Mursi in the previous round of fighting in 2012 when the head of his government, Hesham Qandil was sent to the Gaza Strip during the days of the Israeli operation.

In dozens of speeches, Qaradawi makes it clear that jihad against Israel is the most important type of jihad in the Arab world today. This is the first and foremost of all Muslim problems and all must support it. This is 
Qaradawi's permanent opinion and reflects the views of Hamas as expressed in speeches by Khaled Mash'al, Ismail Heniyeh, Kamal Khatib and Ra'ed Salah, all of them IUMS members. The Islami nation must lead this jihad until the defeat of the Zionist entity.

Why is the jihad in Palestine the most important? How is it different than the jihad in Iran, Afghanistan, Somalia and Syria? One can simply say that we are talking about protecting the holy items of Islam in Jerusalem. The historical argument that the Jews are going to destroy al-Aqsa and build a temple on its ruins is the central reason for this. But, an analysis of the declarations and the writings of al-Qaradawi show that we are talking about an existential war between Islam and Judaism. We are not talking about a war between groups of Muslims who are divided between themselves in regard to the meaning of faith. We are talking about an existential war which will conclude with only one winning side and that will be Islam. From here flows the importance of Palestine and the struggle with Israel. Therefore, one can say that the next round between Israel and Hamas will come soon. It is the obligation of every Muslim to do what he can in order to defend the Islamic lands and most of all Palestine. Hamas is not a terrorist organization, according to this definition, but the Islamic spearhead to destroy the Jewish state.

\section{References}

Abu 'Amer, A. (2013, January). Istiyaa sahayuoni min nataej al-harb al-akhira ala Gaza: Hamas intisart. Filastin al-Muslima, Sheet 1, 32-33.

Albany Tribune News. (2014, March 14). Hamas military wing denies report linking leaders to Egypt attack. Retrieved December 15, 2014, from http://www.albanytribune.com/14032013-hamas-military-wing-denies-report-linking-leaders-to-egypt-attack/

Ali, Y. (Ed.) (2009). Al-Majajer al-Ishraeliya bi-haq al-sha'ab al-Filestini. Beirut: Al-Zaytouna Centre for Studies \& Consultation.

Al-Jazeera. (2014, July 21). As- Shari'a wa-al-hayat, siyasa fi din m'a al-sheikh Yusuf al-Qaradawi. Retrieved August 26, 2014, from https://www.youtube.com/watch?v=pa9vLhNJcF8

As-Sharq channel (2014, September 2). Retrieved from http://elsharq.tv/

Bartal, S. (2012). The jihad way in Palestine. Jerusalem, Carmel.

Bartal, S. (2012, November 18). Hamas and the Islamic winter. Maariv. Retrieved from http://www.al-monitor.com/pulse/politics/2012/11/israels-south-under-fire-hamas-v.html

Drori, M. (2014, December 14). File no. T"f 34838-01-14. State of Israel against Gazawi. Sentence of Khalil Ghazawi in the Jerusalem central court.

Haaretz. (2012, October 23). In official visit to Gaza, Qatari emir endorses Hamas, slams Israeli settlements. Retrieved December 19 , 2013 ,

from

http://www.haaretz.com/news/middle-east/in-official-visit-to-gaza-qatari-emir-endorses-hamas-slams-israeli-settlements-1.4 71861

Inbar, E. (2014, September 1). Hamas was defeated, until the next time. Middle East Forum. Retrieved September 10, 2014, from http://www.meforum.org/4789/hamas-was-defeated-until-the-next-time

Issacharoff, A. (2012, October 24). Qatari ruler's visit to Gaza signals turning point for Hamas. Haaretz. Retrieved December 19, 2013 ,

from http://www.haaretz.com/blogs/east-side-story/qatari-ruler-s-visit-to-gaza-signals-turning-point-for-hamas.premium-1.471898\#

Issacharoff, A., \& Jack, K. (2012, February 6). Abbas to lead Palestinian unity cabinet following Hamas-Fatah deal. Haaretz. $\begin{array}{llll}\text { Retrieved } \quad \text { December } & 19, & 2013,\end{array}$ http://www.haaretz.com/news/middle-east/abbas-to-lead-palestinian-unity-cabinet-following-hamas-fatah-deal-1.411354

Izz ad-Din al-Qassam Brigades. (2009, January 23). Al-Qaradawi: qadiyat Filastin hiye a'adal qadiye fi al-'alam. Retrieved December 19, 2013 from http://www.alqassam.ps/arabic/news1.php?id=30352

Izz ad-Din al-Qassam Brigades. (2009, January 29). Al-Qaradawi: atmani al-shahada fi Gaza walu 'ala kursi mutharaq. Retrieved December 19, 2013, from http://www.alqassam.ps/arabic/news1.php?id=7683 
Izz ad-Din al-Qassam Brigades. (2014, August 21). Al-Qassam mourns three of its leaders in Gaza. Retrieved September 21,2014 from http://qassamps.blogspot.co.il/2014/08/al-qassam-mourn-three-of-its-leaders-in.html

Kam, E. (2012). After the operation: Balance between the two sides. In S. Brom (ed.), After the pillar of defense operation (Gaza Strip: Nov. 2012) (pp. 14-20). Tel Aviv University, Research and National Security Institute.

Khaled al-Sa'ad. (2003). Khtab al-Sheikh Yusuf al-Qaradawi. Vol. 5, Cairo: Maktaba Wahba.

Khomeini, R. (1969). Wilayat Faqih. Beirut: Muassasat tanzim wa-nshar atar Imam Khomeini.

Lake, E. (2014, August 5). Israeli claim: Hamas funded the kidnapper who started the Gaza War. The Daily Beast. Retrieved from http://www.thedailybeast.com/articles/2014/08/05/israeli-claim-hamas-funded-the-kidnapper-who-started-the-gaza-war.html

Levi, E., Kais, R., \& Somfalvi, A. (2014, August 20). Only Deif will decide if the residents of the communities surrounding Gaza will return to their homes, his wife and his son were buried in the Gaza Strip. Ynet. Retrieved from http://www.ynet.co.il/articles/0,7340,L-4560976,00.html

Madina al-Quds. (2014a, September 5). Mudir 'Aam Muasasat al-Quds al-Dawliya Yasin Hamud: Intisar Gaza Ymhad al-Tariq ila al-Quds. Retrieved December 16, 2014, from http://alquds-online.org/index.php?s=news\&id=461

Madina al-Quds. (2014b, September 5). Khalil al-Haya 'Adu al-Maktab al-Siyasi li-Haraka Hamas: Intisar Gaza Saymn'a al-Ihtilal min Fardh Siyadetu ala al-Quds. Retrieved December 16, 2014, from http://alquds-online.org/index.php?s=news\&id=460

Maktab al-Filastini lil-l'alam. (2012, November 16). Al-Qaradawi Yadeu al-Arab aw-al-Muslimin ltajim'aa Safufuom li-Nasra Gaza. Retrieved from http://www.palinfo.com/site/pic/newsdetails.aspx?ItemId=124598

Qaradawi, Y. (1993). Dars al-nakbah al-thaniyah: li-madha inhazamna--wa-kayfa nantasir. Cairo: Maktaba Wahba.

Qaradawi, Y. (2001a). Al-Quds qadiyat kol Muslim. Beirut: Mu'assasat al-Risalah.

Qaradawi, Y. (2001b). A'ada al-hal al-Islami. Beirut: Mu'assasat al-Risalah.

Qaradawi, Y. (2002). Al-Qarya wa-al-kuttab: malameh sira wa-masira. Vol. 1, Cairo: Dar al-Sharuq.

Qaradawi, Y. (2009). Fiqh al-Jihad. Cairo: Maktaba Wahba.

Qaradawi. (2014a, July 7). Al-Qaradaghi Yetlab bi-Intifada Islamiya wa-Arabiya min ajal filastin. Retrieved August 26, 2014, from http://www.qaradawi.net/new/takareer/7364-2014-07-07-14-27-54

Qaradawi. (2014b, July 7). Itihad Ulama al-Muslimin yestankr al-Samet al-'Alami tujaa Katel al-Fta al-Filastini Muhammed Abu Khdeir. Retrieved August 26, 2014, from http://www.qaradawi.net/new/takareer/7366-2014-07-07-14-30-22

Qaradawi. (2014a, July 9). Wa-Aqdashaa wa-iaghaztaa. Retrieved August 26, 2014, from http://www.qaradawi.net/new/takareer/7373-2014-07-09-07-30-56

Qaradawi. (2014b, July 9). Al-Risuni: Surat Sheikh al-Azhar wa-Baba al-Knisah Yejaneb al-Sisi Ta'aks. Retrieved August 26, 2014, from,http://www.qaradawi.net/new/takareer/7374-2014-07-09-07-38-59

Qaradawi. (2014, July 10). Al-Qaradawi: Al-masas bial-Aqsa sa-Yafjar Haba Jamahirya la yetwaqa'a Ahad, Retrieved August 26, 2014, from http://www.qaradawi.net/new/takareer/7324-2014-06-10-15-36-13

Qaradawi. (2014, July 19). Al-Qaradawi: Ada'au kul al-Muslamin an yeahbu li-nasra ahalna fi Gaza. Retrieved August 26, 2014, from http://www.qaradawi.net/new/takareer/7390-2014-07-19-12-14-15

Qaradawi. (2014, July 20). Al-Qaradaghi li-hukam al-Muslimin: Allah mahsabkum wa-al-tarikh yil'an min yekhun. Retrieved August 26, 2014, from http://www.qaradawi.net/new/takareer/7392-2014-07-20-23-08-58

Qaradawi. (2014, July 21). Al-Qaradawi: Wasaf Hamas bial-Irhab Masiba wa-Tghayb lil-Wa'ai. Retrieved August 26, 2014, from http://www.qaradawi.net/new/takareer/7394-2014-07-21-23-35-05

Qaradawi (2014, July 22). Al-Qaradawi: La yejuj an tarek al-mukawma wahadha. Retrieved August 26, 2014, from http://www.qaradawi.net/new/takareer/7397-2014-07-22-07-35-53

Qaradawi. (2014, July 23). Facebook page. Retrieved August 13, 2014, from https://www.facebook.com/pages/\%D8\%A7\%D9\%84\%D8\%B4\%D9\%8A\%D8\%AE-\%D9\%8A\%D9\%88\%D8\%B3\%D9\%8 1-\%D8\%A7\%D9\%84\%D9\%82\%D8\%B1\%D8\%B6\%D8\%A7\%D9\%88\%D9\%8A/351459878354757

Qaradawi. (2014, July 26). Al-Qaradawi: Mawqaf ahal Filastin raf'at ras al-Umma Kulha. Retrieved August 26, 2014, from http://www.qaradawi.net/new/takareer/7406-2014-07-26-14-39-04

Qaradawi. (2014, August 9). Al-Qaradawi yenfi saha tasrihat tsbat lahu hawal al-Jihad fi Filastin. Retrieved August 26, 2014, from http://www.qaradawi.net/new/takareer/7417-2014-08-09-21-24-15

Qaradawi. (2014, August 21). Al-Khatib: Filastin hiye al-qadiya al-markaziya lal-'umma wa-satabqi kadhlak. Retrieved August 26, 2014, from http://www.qaradawi.net/new/takareer/7449-2014-08-21-13-34-36

Qaradawi. (2014, August 24). Al-Bayan (Mohammad) Khatami li-Jam'aiya al-'Amumiya al-Rab'a lil-Itahad al-'Alami Li-Ulama 
al-Muslimin. Retrieved August 26, 2014, from http://www.qaradawi.net/new/takareer/7455-2014-08-24-20-46-26

Qutb, S. (1993). Ma'rakatuna ma' al-Yahūd. Cairo: Dar Al-Sharuq.

Shabi, A., \& Shaked, R. (1994). Hamas from believing in God to the way of terror. Jerusalem: Keter.

Shubaka Filastin lil-hawar. (2014, August 23). Interview with the leader Khaled Mash'al on the Yahoo web side. Retrieved August 26 ,

2014 ,

from https://www.facebook.com/paldf/photos/pb.114312025247339.-2207520000.1409179086./866117693400098/?type=3\&theat er

The General National Security Service-Shabak. (2009, September). The charity coalition, the charting and analysis of the terrorism money system. October 20, http://www.shabak.gov.il/publications/study/Pages/coalition_he.aspx?webid=a3db3c16-25d8-423d-98df-eb1b9253ab9

Ynet. (2014, August 23). Mash'al: Hamas murdered the boys is a legitimate activity. Retrieved August 26, 2014, from http://www.ynet.co.il/articles/0,7340,L-4562324,00.html 